\title{
Cultural Strategy of Chinese Culture based on Cultural Identity —A Case Study of Foreign Language Teaching in Colleges and Universities
}

\author{
Jiang Hua \\ Bohai University, Jinzhou, Liaoning, 121013
}

Keywords: Cultural Identity; Cultural Soft Power; College Foreign Language Teaching

\begin{abstract}
Cultural soft power is a strategic force that can not be ignored in the development of the country. It profoundly affects people's values and cultural transmission. Cultural soft power as an important part of enhancing the national comprehensive national strength, much attention of our party and people, but at present in the major foreign language teaching in colleges and universities also lack the cultural soft power strategy construction. Based on this background, this paper tries to explore the specific strategies of foreign language teaching in modern colleges and universities under the guidance of cultural identity, hoping to help foreign language students to eliminate the crisis of cultural identity, so as to enhance students' cultural consciousness, Fundamentally enhance the soft power of our culture.
\end{abstract}

\section{Introduction}

Since the 18th National Congress of the Communist Party of China, President Xi Jinping has repeatedly proposed that "the promotion of cultural soft power is related to the revival of the nation. It is an important prerequisite for the realization of Chinese dream." Modern foreign language education is a cross-cultural quality education, The process should not only pay attention to language teaching should also focus on culture and education. With the gradual integration of the global economy, national culture began to collide and conflict become inevitable phenomenon. China should understand the promotion of cultural soft power, to enhance the national comprehensive national strength of the importance. China's culture and the world culture in the process of collision, Western culture seriously affect the cultural identity of foreign language students, so many students advocate Western culture, ignore the fine culture of the nation's phenomenon, reduce the national culture of self-confidence. Therefore, our country foreign language teaching should strengthen the culture and education, the national culture inheritance and innovation as a new mission.

\section{The Basic Theory of Cultural Identity}

Cultural identity is a new term in recent years. It refers to the collective feeling of culture in a group. Cultural identity for the cultural soft power of the impact will be strong, if a national identity of foreign cultural identity, it will seriously threaten the country's cultural soft power, reducing the cultural self-confidence of the nation, so that its national cohesion and political The system was disintegrated. On the contrary, a country's people have a high sense of identity in their own culture, then it will certainly enhance the nation's cultural self-confidence, thereby enhancing the country's national cohesion and national comprehensive strength. From the psychological point of view, identity generally refers to the individual's self-awareness, is the identification of individual self-identity. For the country, cultural identity refers to the feelings of a person or group for a common culture. Cultural soft power affects our national cohesion and cultural identity, thus affecting the national nationality in the international status of the level. In today's society, countries will be cultural soft power as an important component of the national comprehensive strength. "The 
promotion of Chinese cultural soft power has affected China's international status and strengthened the education of college students' cultural quality, which is of great importance to enhance the soft power of national culture. Our country should regard the construction of cultural soft power as an important strategy [1]."

\section{The Soft Power of Culture and the Contradiction of Foreign Language Teaching in Colleges and Universities}

In this paper, cultural identity mainly refers to the foreign language college students in China on the cultural identity of the West, specifically that they are in the Western culture in the cognitive and emotional acceptance and recognition. It is well known that language expression has a high social nature, it is an important part of cultural identity, but also an important factor affecting cultural identity, its role in the importance of cultural identity can not be ignored. Some scholars in China have pointed out that English facilitates communication and communication, but it also infiltrates the culture of other countries.

China's foreign language education in colleges and universities is mainly to educate the language, seriously affecting the students of the two cultural identity. The famous American scholars believe that "cultural identity seriously affects the national and national identity, it affects the national and national harmony and stability.Of course, cultural identity and cultural identity construction needs to go through a long process, college foreign language education will obviously improve students' The foreign language teaching is not only the aggression against Chinese language, but also the educational content in education is not consistent with the local culture. Therefore, the foreign language teaching is not only the Chinese language, the foreign language teaching as a humanities education, should strengthen our language and cultural stand, calmly face other countries cultural aggression and infiltration. Our country should attach importance to the role of language for the shaping of national cultural image, re-examine foreign language education for Chinese cultural identity The impact of foreign language education in the foreign language education should strengthen the identity of the national culture, in order to achieve a real cross-cultural exchanges and integration [2].

\section{The Strategy of Enhancing the Soft Power of Chinese Culture in Foreign Language Teaching in Colleges and Universities}

Foreign language plays an important role in intercultural communication, and it is an important tool for Chinese and foreign culture and ideological communication. China's foreign language teaching should not only blindly spread the Western culture, but also through foreign language teaching to carry forward the Chinese nation's outstanding culture. However, the process of foreign language teaching in our country only focuses on the western culture, ignoring the spread and development of its own culture. This unequal cross-cultural communication phenomenon is in foreign language teaching materials reflect the most obvious. Therefore, our foreign language educators should assume the responsibility of intercultural communication. The preparation of foreign language teaching materials should increase the essence of Chinese culture so that students can learn foreign languages and deepen their understanding of their own culture.

Chinese and foreign language teaching should strengthen the comparison of Chinese and Western culture, Chinese and Western cultural knowledge is an important part of foreign language teaching. China's foreign language teaching should not only enhance the students' ability of language communication, but also strengthen the cultural meaning of foreign language vocabulary and grammar in the deeper level of foreign language vocabulary and grammar teaching. In the process of teaching, foreign language educators should instill the cultural knowledge of both countries, and combine foreign language teaching with cultural teaching. In the teaching of two countries' language and culture, the foreign language educators should pay attention to explain the cultural differences between the two countries in order to enhance the students' understanding and understanding of Chinese and Western culture and reduce the conflict between our students' cultural 
collision. Foreign language students can effectively carry out cross - cultural communication and dissemination [3].

China's foreign language teaching in colleges and universities can promote the cultural exchange and development of various countries, but the lack of foreign language translation in our literature, there are fewer Chinese and foreign translation and poor quality and so on. China should strengthen the importance of language teaching to the development of the country, and the number of works in Chinese history is numerous, but our country lacks the corresponding foreign language translation, which leads to the inability of our culture to get out of the international arena. Therefore, the translators of foreign language translators in our country need to strengthen their awareness of cross-cultural communication, actively participate in the construction of Chinese national culture soft power and propaganda work, strengthen the awareness of cross-cultural communication among students in the process of foreign language teaching, strengthen the translation of Chinese and foreign languages Ability. In the process of foreign language teaching, we should also strengthen the expression of Chinese and Western culture and strengthen the mission of students to spread the Chinese national culture.

College foreign language teaching by time and place, resulting in foreign language teaching results can not achieve the desired results. China's foreign language teachers in colleges and universities must pass a variety of channels for foreign language teaching students to expand the practice of foreign language culture in colleges and universities, is the Chinese college students in Western culture and education an important way. China's foreign language teaching in colleges and universities can carry out cross-cultural exchange lectures in the course of the lectures for students on the cultural atmosphere and customs and habits introduced; In addition, China's colleges and universities can also share cross-cultural classroom learning resources, with campus radio on Chinese and foreign culture Publicity can also be organized by a variety of Chinese and foreign cultural knowledge contest, to enhance students' understanding of Chinese and foreign culture and understanding; teachers in the classroom teaching for students to recommend cultural connotations of Chinese and foreign films or books. In short, college foreign language teaching should be combined with the characteristics of national culture, targeted to the spread of the Chinese culture and carry forward [4].

\section{Conclusion}

To sum up, with the economic globalization and cultural globalization become increasingly obvious days, foreign language teaching in colleges and universities to cultivate cross-cultural exchange talent has an important role. There is a lot of contradiction between the soft power of Chinese culture and the foreign language teaching in colleges and universities, and the foreign language education in colleges and universities is bound to weaken the cultural identity of Chinese Mandarin, which leads most students to pay attention to western culture and neglect the outstanding cultural phenomenon of national nationality. Therefore, China's colleges and universities should strengthen the emphasis on the promotion of cultural soft power, foreign language teaching content should be appropriate to the Chinese local culture, in the teaching process of Chinese and Western cultural soft power comparison to strengthen the translation of foreign language teaching attention, but also need to strengthen the university foreign language Extracurricular cultural practice. Only in this way can we improve the cultural consciousness of our college students, so as to cultivate high-quality cross-cultural communication envoy.

\section{References}

[1] Xiao Kuiwei. Application of "Nationalization" Strategy and Its Implications for Constructing Cultural Soft Power - Taking Lin Yutang's Intercultural Communication Practice as an Example [J]. Journal of Jimei University, 2017, 02: 87-92 The

[2] Jiang Yumei. The Experience and Reference of Enhancing the Soft Power of the National 
Culture in the Key Period of the Great Rejuvenation of the Nation - Based on the Perspective of "Telling the Chinese Story" [J]. The Frontier, 2015, 03: 29-33.

[3] Li Peilin. Enhancing the international voice and enhancing the cultural soft power - Speech on "The First Issue of Chinese Journalism" in the "English Quarterly Journal" [J]. World Religious Studies, 2015, 06: 1-2.

[4] Zeng Hongjun, Wang Mei. When the construction of enterprise culture - see how China Huadian Group Company to enhance the soft power of enterprises by cultural innovation [J]. Contemporary Electric Power Culture, 2017, 04: 17-25 